\title{
Australia's Corporate Law Reform and the Market for Corporate Control
}

\author{
Philip Brown and Raymond da Silva Rosa
}

\begin{abstract}
USTRALIA's Corporations Law includes stringent regulations governing the A takeover of public companies. Since 1969, the regulations have reflected 1 the influence of the so-called 'Eggleston principles' (named after Sir Richard Eggleston, chairman of the committee which recommended them), which promote 'equity' and 'disclosure' as paramount concerns. The regulatory objective, as noted by the Corporate Law Economic Reform Program (CLERP, 1997:7),
\end{abstract}

is to improve market efficiency. Specifically, regulation is directed at achieving an appropriate balance between encouraging efficient management and ensuring a sound investor protection regime, particularly for minority investors.

According to the Commonwealth Treasurer, Peter Costello (1997),

CLERP is a program to modemise Australia's Corporations Law and give it an economic focus. ... [Its] aim is to introduce world's best practice in business regulation. It is part of the government's broader goal of making Australia a leading financial centre in the region. CLERP is designed to harmonise Corporations Law with pro-enterprise, projobs and pro-investment objectives.

In this article, it is argued that the provisions of the Corporations Law impede the achievement of its objectives with respect to takeovers. The focus on equity and disclosure discourages economic efficiency, to the detriment of small shareholders, by not giving appropriate recognition to the costs of acquiring information about the potential target. Under the existing laws governing takeovers and the reforms suggested by CLERP, an acquiring firm must equitably share the gains among all shareholders of the target company, not just those controlling the target company. It must also disclose to the public its information about the target. But this dilutes the benefits of searching for profitable targets, without commensurately sharing the search costs. This must discourage takeovers from occurring in cases where all the

Philip Brown is Professor of Accounting and Raymond da Silva Rose a lecturer in the Department of Accounting and Finance, at The University of Western Australia. 
potential gains may be diluted, so leaving control of the potential target remains with the incumbent management. But efficiency requires that assets should be controlled by investors who can make the best use of them.

If CLERP is to achieve its goals, its proposals for takeover regulation need to go further. In particular, the Corporations Law would make a more effective contribution towards shareholder equity if it focused on defending rather than eroding the property rights of shareholders.

\section{The CLERP Proposals on Takeover Regulation}

Australian government regulation of takeovers has, since the early 1960 s, vacillated between attempts at rigid control and a practically laissez-faire approach. It is not just government that has been inconsistent. On 24 April 1986, The Australian Financial Review ran an editorial which labelled as 'futile' and 'dangerous' a justreleased study on takeovers because 'it may be used to justify increased regulation of takeovers'. This was alarming because 'policies that hinder takeovers quite simply prevent resources being used by those who can get the most of them'. Five years later, on 21 May 1991, The Australian Financial Review had turned full circle. Its editorial claimed that 'takeover raids, even unsuccessful ones, can have a painfully corrosive effect on companies, morale often suffers and industrial performance flags. ... The intangible cost of diverted management attention and stultified growth is unlikely ever to be known'. It is difficult to explain this substantial turnaround, since no major study on the effects of takeovers in Australia which might have caused a revision of opinion had been released since the date of the first editorial.

This variation in elite views on the benefits of low barriers to entry in the market for corporate control and the magnitude of the wealth effects at stake underline the need for a coherent, consistent framework to evaluate regulatory policy in this area. But CLERP does not inspire confidence that the regulatory authorities have a clear framework in place. Its paper on corporate control begins, encouragingly, with the claim that 'the threat of takeover provides a strong incentive for company directors and management to use capital efficiently. ... It provides market-based incentives to encourage adequate corporate performance and provides a penalty where this is not achieved' (pp. 7-8). 'The implication of this argument is that the government should strive to eliminate impediments in the market for corporate control. But the proposed reforms fall well short of what could be done.

There are four principal reforms. These are:

- giving a specialist takeover panel the primary role in takeover dispute resolution to improve efficiency and provide a commercial focus;

\footnotetext{
'All page references are to CLERP's Paper No. 4, 'Corporate Control: A Better Environment for Productive Investment'.
} 
- introducing a new compulsory acquisition power to allow any person who holds 90 per cent of a class of securities to acquire the remaining securities in that class at a fair price (whether or not a takeover bid has been made);

- extending the company takeover rules to listed managed investment schemes, so that listed-scheme managers face the same competitive pressure to perform, and unit holders have the same takeover protection, as companies; and

- introducing a mandatory-bid rule, which would allow a bidder to exceed the current statutory shareholding threshold (currently 20 per cent of all shares in a class) before being obliged to make a general takeover offer.

The mandatory-bid rule is particularly significant because, if passed into law, it would substantially increase the rewards from identifying underperforming companies. Under current legislation, a potential acquirer is obliged to disclose to all investors valuable information about a target by making a public bid for all shares in the target once it has acquired 20 per cent of the target's ordinary shares. This promotes a public 'auction' for the target where the eventual winner is not necessarily the company that first identified the target. Even if the firm that first identified a target manages to win its prize, the public auction will have forced it to concede a large proportion of its prospective gains from the purchase. The shareholders of potential target firms may appear to be the beneficiaries of the current system; but they bear the opportunity cost of missing out on takeover bids from potential acquirers who are deterred by the high regulatory costs.

The mandatory-bid rule (or, as it is sometimes termed, the 'follow-on rule') is consistent with the government's avowed intention to promote market-based incentives to encourage adequate corporate performance. In this light, it is disappointing that the mandatory-bid rule's potential to effect beneficial outcomes will be reduced by qualifying provisions that restrict its application. For instance, potential bidders holding 20 per cent or more of the target firm's shares will not be able to acquire control without making a public bid that triggers a public auction for the target.

\section{The Eggleston Principles}

The principal stumbling blocks to an overhaul of existing policies in favour of those that would promote increased activity in the takeovers market are the four Eggleston principles that were, ironically, drafted with the intention of protecting the interests of target-firm shareholders, especially minority or non-controlling shareholders. Rather than challenging them as sound guides to takeover regulation, CLERP's paper attempts to accommodate them.

The four Eggleston principles are as follows:

1. the bidder's identity should be known to shareholders and directors of the target; 
2. shareholders and directors of the target should have a reasonable time to consider the bid;

3. the bidder should give sufficient information to the shareholders to enable them to form a judgment on the merits of the bid (the 'disclosure principle'); and

4. each shareholder should have an equal opportunity to participate in the benefits offered under a bid (the 'equal opportunity principle').

The four principles are discussed in order of importance.

The disclosure principle. The CLERP paper recognises that the disclosure principle stems from a presumption that legislation should require a uniform distribution of information among the participants in the market for corporate control. It argues that 'Although there are costs of disclosure, they are clearly outweighed by the benefits of facilitating an efficient market and protecting investors' (p. 10). Importantly, the costs of disclosure are borne entirely by the bidder: 'Prospective bidders can expend substantial resources identifying underpriced companies and determining how management can be improved. ... These search costs may not be able to be recovered by the bidder, particularly if a rival bidder acquires the company. In such a case, the rival bidder will "free-ride" on the search costs paid by the initial bidder' (p. 9).

The concern with ensuring informational balance among bidders and the shareholders of their target firms reflects a confusion between the ideal of efficient markets and the processes that contribute towards market efficiency. Efficient markets incorporate several desirable attributes, including that prices reflect available information. However, information is costly and will not be produced unless there is an appropriate return. As the paper recognises, the incentive to produce such information is reduced, if not eliminated, by forcing bidders to broadcast valuable private information without allowing them to capture the gains. What appears not to be appreciated is that target shareholders are thereby deprived of one of the principal market mechanisms that assist them in ensuring their firms' managers turn in 'an adequate corporate performance'. The requirement for informational balance among bidders and target firms' shareholders effectively undermines the market for corporate control by imposing a substantial barrier to entry.

The equal opportunity principle. The primary motivation of the equal opportunity principle was apparently a concern about promoting 'fairness and encouraging investor confidence in the market' (p. 11). The paper notes that the equal opportunity principle is 'an integral element of the takeover provisions of the Corporations Law. ... Even if there is no breach of the takeover provisions, depriving shareholders of an equal opportunity to participate in benefits accruing from a bid may constitute "unacceptable circumstances", leading to a referral to the Panel' (p. 11). It goes on to assert that "Without the investor protection provided by the equal opportunity 
principle, it may be less likely that smaller investors would invest directly in the market, which could affect market liquidity and confidence' (p. 14).

Since critics of the equal opportunity principle risk being unfairly tarred with the same brush as misogynist critics of motherhood, it is important to clarify what is meant or intended by the term 'equality of opportunity'. The paper's discussion implies that equality of benefits or outcomes will reflect an equal opportunity environment; and this presumption informs its view of what the appropriate regulation should be. However, in an equal opportunity environment investors will devote different amounts of resources to gathering information; and their returns will, on average, reflect their different levels of investment. This line of reasoning suggests that insisting on equality of outcomes is not merely inequitable but also inefficient, given that it eliminates investors' incentives to gather costly information.

Because of its uncritical acceptance of the equal opportunity principle, the paper does not canvass the equity implications of depriving the controlling shareholders of their property rights to the premium for control paid by the acquirer, although it does acknowledge that the principle 'could result in a lower premium obtainable by controlling shareholders, where the bidder decides to pay the same total premium and distribute it amongst all target shareholders' (p. 15). In sum, the discussion begs the question whether the investor who purchases a non-controlling parcel of shares in a company and who holds them passively is entitled to a proportionate share of the premium for control. Arguably, equity requires that the entire premium for control should accrue only to the shareholders who can deliver control of the target company.

It is also noteworthy that the paper does not provide any evidence to support the claim that smaller investors exert a significant influence on market liquidity or confidence. On the face of it, the equal opportunity principle acts to reduce rather than increase small investors' confidence, by decreasing their access to the market for corporate control. However, the paper does attend to the efficiency implications of the equal opportunity principle. It states that 'the equal opportunity principle potentially creates higher costs for market participants, reducing incentives to engage in takeover activity. Without the principle, takeover costs could be lower, thereby increasing incentives to bid for a target company and leading to greater efficiency through the prospect of increased takeover activity' (p. 15). But it is then argued that the increase in shareholder protection afforded by the principle gives rise to greater investor confidence, the benefits of which outweigh the costs.

It is difficult to appreciate how reducing shareholders' access to the market for corporate control can serve to increase their confidence. As noted earlier, the paper explicitly recognises that an active market for corporate controls reduces investors' exposure to the risk of managers pursuing non-value-maximising behaviour; yet it does not consider the cost of losing this benefit when evaluating the net attraction to investors of the equal opportunity principle.

Commendably, the paper does acknowledge that the equal opportunity principle is not the only means by which the interests of small (or 'retail') investors can be protected. Retail investors can choose to invest in managed funds or may reduce 
'the risk of becoming a minority shareholder unable to sell their shares at the pretakeover price' by diversifying their funds. However, the paper argues that diversification 'would be a second best alternative to the equal opportunity principle as, in practical terms, diversification can be difficult to achieve without incurring substantial costs' (p. 15). Again, no evidence is provided in support of the assertion, which is questionable given the availability and potential for growth in pooled investment funds.

In sum, it is difficult to agree with the paper's conclusion that 'The equal opportunity principle enhances aspects of the market that are essential: market integrity and investor protection' (p. 16). The arguments for the opposing view are more convincing.

The regulations stemming from the application of the disclosure and equal opportunity principles impose the largest direct costs on bidders seeking to enter the market for corporate control. The indirect but nevertheless real costs are borne by the target shareholders. These indirect costs may be higher than the direct costs, given that bidders have alternative investment opportunities.

The revelation of identity principle. The first Eggleston principle - that the bidder's identity be known to shareholders and directors of the target - is embodied in provisions of the Corporations Law such as those affecting substantial shareholders. Under these provisions, investors are required to lodge a notice that they are substantial shareholders once they are aware that they have a relevant interest in 5 per cent or more of the total number of shares issued by a company. The notices have a significant impact; substantial shareholder notices are interpreted by the market as signalling takeover intentions, and their filing by firms active in takeovers tends to drive up the share price of the prospective target firm.

As with all legislation that effects wealth transfers, the provisions concerning substantial shareholder notices benefit some stakeholders at the expense of others. The direct costs of the principle are borne by the substantial shareholders who fail to capture the full benefit from their information. Prospective target-firm shareholders gain from the knowledge that an offer for their shares is more than likely imminent. Although, from an economy-wide perspective, the first Eggleston principle may appear to exhibit the properties of a zero-sum game because the profits from the increase in information are not lost but partially transferred to the target shareholders, the fact is that depriving substantial shareholders of the full gains from the information decreases their incentives to search for information in the first place. The long-term effect is a decrease in the efficiency of resource allocation as less information is produced. Further, the long-run effects are also negative for target shareholders, given that the reduction in information about firms leads to a decreased incidence of takeover bids.

The ceiling for notification of substantial shareholder status has been reduced from a 10 per cent ownership level to 5 per cent. The decrease has made the provisions more expensive to comply with and more expensive to administer; it has also made it more difficult for bidders to capture the full gain from information. 
Given these costs, the alleged benefits of the 5 per cent rule relative to the previous 10 per cent rule should be re-evaluated.

The reasonable time principle. The Eggleston principle that shareholders and directors of the target have a reasonable time to consider the bid is operationalised by the requirement in the Corporations Law that bidders keep their offers open for at least one month during the formal offer period, which begins 14 days after the takeover announcement. In effect, the Corporations Law forces bidders to write a free put option at no cost to the shareholders of the target company for a whole six weeks; that is, the law compels bidders to maintain a minimum price for the target's shares for the duration of the offer, a right which is valuable to the target shareholders but for which they bear no obvious cost. But of course they do bear a cost, implicit in a lower bid price, or, in some cases perhaps, no bid at all.

Surely, six weeks to evaluate the merits of an offer is far longer than is commercially reasonable in today's market. A reduction to 14 days in the formal offer period would lower the cost to the bidder without prejudicing the target shareholders' ability to evaluate the offer. Regardless of the amount of time available to shareholders to evaluate an offer, it is always in their interests to delay making a decision until the last moment, because accepting it can kill the option. The tendering of acceptances late in the stipulated offer period should never be seen as evidence that the whole period was required properly to evaluate the offer. It is typically the optimal response to any normal bid.

\section{Evaluating Barriers to Entry in the Market for Corporate Control}

Corporate takeover bids are frequent occurrences. Argus and Finn (1992) report that between 1971 and 1990 up to 16 per cent of all listed companies were subject to a takeover bid in a given year. That is an underestimate of the number of listed firms involved in takeover activity, since many of them bid for companies that are unlisted or foreign-based. ${ }^{2}$ Over the past decade, a large majority of the top 100 firms in terms of market capitalisation made at least one acquisition that exceeded 10 per cent of their market capitalisation.

The high incidence of takeover bids indicates that investors, as a whole, have ample opportunities to develop expertise in evaluating bids and therefore can appropriately price the shares of the companies involved in them. Expansion by merger is not an exceptional event but an integral element of the investment plans of most successful companies. Further, although managerial hubris and aggrandisement may motivate some acquisitions, takeover activity is too broadly based among successful companies to sustain the charge that they are its principal spur. In any event, investor reaction to takeover bids permits a direct test of the manage-

\footnotetext{
2

A survey in 1996 by the financial services group, Ernst \& Young, found that 'while most attention has focused on listed takeovers, at least three-quarters of all acquisitions occurred off market. These involved private companies or businesses, unlisted public companies and off-shoots of public listed companies' (The Australian Financial Review, 7 February 1996).
} 
rial hubris-cum-aggrandisement hypothesis. If hubris is a principal motivation, we would expect the share returns to acquiring firms to decline on announcement of a takeover bid. (We review the Australian evidence below.)

The high incidence of takeover bids may suggest that perhaps the barriers to entry in the market for corporate control are not substantial and that their associated efficiency costs are therefore not substantial either. The flaw in this argument is that high barriers to entry in the market for corporate control do not entirely preclude entry. However, high barriers ensure that only takeovers offering the opportunity to reap egregiously large profits will be contemplated by a potential acquirer. High barriers to entry deprive shareholders of the opportunity to profit from a reallocation of corporate assets that yields a net gain that is less than the cost of overcoming the barriers.

It is difficult to derive a direct estimate of the cost of barriers to entry in the market for corporate control. However, the sharemarket performance of target firms relative to that of other firms in the pre-bid period provides one indirect measure of their high cost. The high level of prospective profits required to make a firm attractive to a potential acquirer is more likely to be available in firms that are substantially underperforming relative to other firms, so evidence of substantial underperformance by firms that are subsequently the subject of takeover bids is consistent with the existence of high barriers to entry. This is because, in a takeover market with no barriers to entry, investors will anticipate that underperformance that may be remedied by takeover will not persist and so the share returns of potential target firms will not substantially underperform the rest of the market in the pre-bid period.

\section{Sharemarket-based Evidence}

Sharemarket-based evidence is relevant to the debate over the market for corporate control because the focus of the takeover provisions of the Corporations Law is on delivering equitable sharemarket outcomes to the shareholders of target firms. When evaluating the evidence, it is important to bear in mind that studies of investors' responses to corporate events such as takeover bids do not assume that markets are omniscient or unfailingly prescient. The critical assumption is that market participants evaluate companies' prospects in an unbiased fashion and have strong motivations to do so. Given the intense competition to achieve opportunities for abnormal gain in the sharemarket, we may confidently expect that any systematic bias in the evaluation of companies' prospects will not persist.

Notwithstanding the above, sceptics of the utility of sharemarket-based studies may point to the now well-established body of evidence that indicates the apparent existence of market inefficiency, defined as the persistent opportunity to earn positive abnormal returns from relatively freely available information. Among the earliest and best-publicised of these alleged anomalies is the so called 'size effect', which refers to a systematic negative association between firm size and return, even after controlling for risk and other apparently relevant factors. 
Investigation into market anomalies is an intriguing area of research in finance because the anomalies defy obvious explanation. However, it is pertinent that despite the venerable age (by the yardstick of financial markets) of many of the alleged anomalies, none of the publicised ones has passed the ultimate test: the ability persistently to achieve for investors positive abnormal returns when investing real dollars. Reports that less than half of investment-fund managers outperformed the All Ordinaries Index in the 1997 calendar year indicate that market efficiency, defined as the unbiased pricing of companies' prospects, is the depressing or reassuring (depending on one's approach to selecting stocks) reality for the overwhelming majority of investors.

Notwithstanding that investor experience indicates that the 'anomalous' empirical regularities in share returns cannot be exploited to achieve persistent abnormal returns, it is apparent that share market studies that use historical data need to control for these regularities when assessing investor reaction to corporate events. This is the approach the present authors adopted in reviewing the shareholder wealth consequences of takeover activity by firms listed with the Australian Stock Exchange (ASX) (Brown \& da Silva Rosa, 1997). Our study measured the abnormal performance of a virtually exhaustive sample of the ASX-listed firms that were involved in takeover bids between 1975 and 1990. Each sample firm's performance was assessed over two distinct periods: a pre-bid announcement period, defined as the time spanning three years prior to six months before the month of the takeover bid announcement; and a bid announcement period, defined as the seven months centred on the month in which the takeover bid was announced (that is, the bid period begins three months before the month in which the takeover bid was announced and ends three months after it). These operational definitions are consistent with those adopted in similar studies and were based on a judgment that the sample firms' pre-bid period performance did not incorporate takeover-related price effects, while their performance over the bid period includes most of the takeoverrelated impact on share price.

Target firms' pre-bid performance was unambiguously poor. The sample of 1,371 target firms on average lost 23.3 per cent over the pre-bid period, after controlling for market wide and size-related movements in share prices. This poor performance was reversed on the announcement of a takeover bid. Over the bid announcement period, the target firms gained, on average, 25.5 per cent, after controlling for all non-takeover related factors. This translates into a gain of $\$ 15$ billion returned to the shareholders of the sample of target firms directly as a result of takeover activity. Bidding firms also did well out of takeovers. Their takeoverrelated return around the bid announcement period averaged 5 per cent, which, given their market capitalisation, corresponds to a gain of $\$ 5$ billion. The results we reported are consistent with those of other studies, such as Bishop, Dodd and Officer (1986). Interestingly, we did not find that these positive returns were reversed in the months that followed the bid. 


\section{Summary and Conclusions}

An active market for corporate control plays an important role in facilitating capital investment through its function as a monitoring and disciplinary mechanism. It protects investors' interests by providing potential bidders with incentives to search for opportunities to reallocate corporate assets to higher-valued uses. Takeovers create value through the removal of underperforming management or the exploitation of potential synergy. The sharemarket evidence strongly supports this view.

The Corporations Law in Australia aims to improve efficiency in the market for corporate control by facilitating opportunities for efficient management and by providing a sound regulatory regime of investor protection. The investor-protection provisions are framed with reference to the four so-called Eggleston principles. However, the Eggleston principles result in confiscating from bidding firms the benefits that accrue from identifying underperforming corporate assets. The appropriated benefits are transferred to target shareholders. The presumably unintended consequence of such wealth transfers is that the return to resources devoted to identifying underperforming assets is significantly reduced and corporate assets are not employed to their best economic advantage.

Reform of the takeover-related provisions of the Corporations Law aimed at protecting property rights to information would go a long way towards securing equity and efficiency in the market for corporate control.

\section{References}

Argus, J. \& F. Finn (1992), 'Analysis of the determinants of aggregate takeover activity' (second draft), Department of Commerce, University of Queensland (September).

Bishop, S., P. Dodd \& R. Officer (1986), Australian Takeovers: The Evidence, 1972-1985, Centre for Independent Studies, Sydney.

Brown, P. \& R. da Silva Rosa (1997), 'Takeovers: Who Wins?', JASSA: The Journal of the Securities Institute of Australia, Issue 4 (Summer): 2-5.

Corporate Law Economic Reform Program (CLERP) (1997), Corporate Control: A Better Environment for Productive Investment, Canberra (Paper No. 4) at htp://www.treasury.gov.au.

Costello, P. (1997), Press Release, Canberra (8 September). 